BIOMEDICAL AND BIOSOCIAL ANTHROPOLOGY
$\begin{gathered}\text { Official Journal of the International Academy } \\ \text { of Integrative Anthropology } \\ \text { journal homepage: http://bba-journal.com }\end{gathered}$

\title{
CORRELATIONS OF CARDIOINTERVALOGRAPHIC INDICATORS WITH CONSTITUTIONAL CHARACTERISTICS IN ATHLETES OF MESOMORPHIC SOMATOTYPE
}

Sarafyniuk L.A., Syvak A.V., Yakusheva Yu.I., Borejko T.I.

National Pirogov Memorial Medical University, Vinnytsya, Ukraine

\section{ARTICLE INFO}

Received: 22 February, 2019

Accepted: 20 March, 2019

UDC: $612.172: 572.51: 796.42$

CORRESPONDING AUTHOR

e-mail: Isarafinyuk@gmail.com Sarafyniuk L.A.
The topic of sports, physical fitness and adaptive abilities of a person to the influence of physical activity of different intensity has become highly relevant in recent years. The aim of the work is to establish correlations between the indicators of heart rate variability and parameters of the external structure of the body in young athletes of mesomorphic somatotype. The study involved 29 athletes between the ages of 17 and 21 with a high level of sportsmanship and more than 3 years of experience. All athletes had a track and field athletic load with maximum (100 m, $200 \mathrm{~m}$ and $110 \mathrm{~m}$ hurdles) and submaximal (running on $400 \mathrm{~m}$ and $800 \mathrm{~m}$ ) work intensity. We conducted a study of heart rate variability on the cardiac computer diagnostic complex "OPTW" following the recommendations of the European and North American Cardiac Association (1996). Variable heart rate, statistical and spectral cardiointervalographic indices were determined. Anthropometry was performed by the Bunak method (1941), somatotypological study - by the calculated modification of the Heath-Carter method (1990), determination of the component composition of body weight by the method of Matejko (1921). In the package "STATISTICA 5.5" correlation analysis was performed using the nonparametric Spearman statistical method. Cardiointervalographic findings were found to be statistically significantly correlated with a small number of body sizes and somatotype components and body weights in adolescent athletes belonging to the mesomorphic somatotype. Indicators of variational heart rate did not have numerous reliable and unreliable relationships of average strength with somatic parameters. The data of correlation analysis of indices of variational pulsometry showed that in athletes with increase in width and thickness of the torso and decrease in the circumference of the shin and chest was more pronounced sympathicotonia, and with the reduction of fat component increased the influence on the heart of the parasympathetic system. Statistical indicators of heart rate variability with constitutional parameters had significant inverse correlations of mean power. Among all statistical indicators of heart rate variability, the PNN50 had the strongest and most significant correlations with anthropometric dimensions. The least significant correlations with constitutional characteristics in mesomorphic athletes had spectral indices related to skin-fat thickness, trunk diameters, and lower limb segment circumferences.

Keywords: correlations, cardiointervalographic indicators, anthropometric dimensions, somatotype, track and field athletes.

\section{Introduction}

In recent years, the topic of sports, physical fitness and adaptive capacity of a person to the influence of physical activity of varying intensity has become very relevant [13, 15]. There is a growing in number of publications regarding the relationship between gender, age, ethnic and constitutional characteristics of a person $[10,11,18,20]$. Particularly noteworthy are the work on correlation with and the chosen sport $[1-3,7,22,27,34]$. Given the frequent deaths among schoolchildren during physical education and among professional athletes [8], studies aimed at identifying problems of cardiovascular pathology among the younger generation have become of high national importance [35].

The modern informative method of diagnostics of the 
functional state of the cardiovascular system, the evaluation of adaptation mechanisms and the stage of tension of regulatory mechanisms is the assessment of heart rate variability $[17,23,26,30]$, which reflects the activity of sympathetic and parasympathetic units of regulation of cardiac activity [9, 24, 28, 29]. Timely detection of abnormalities in the regulation of the cardiovascular system can not only prevent pre-pathological conditions, but also prevent them. Given that the adaptation and morphofunctional development of athletes are closely interrelated $[9,23,24]$, it is interesting to study the question of the dependence of cardiointervalographic indicators on the constitutional features of the organism from a theoretical and practical point of view. Unfortunately, there are few studies concerning the characteristics of vegetative homeostasis indices in highly skilled athletes of a particular sport belonging to different somatotypes [32]. And the study of correlation relationships of rheocardiographic indices with anthropometric and somatotypological characteristics in athletes of individual constitutional type was not conducted at all. Therefore, the aim of our work was to establish correlations between heart rate variability indices and parameters of external body structure in youth athletes of mesomorphic somatotype.

\section{Materials and methods}

The study was performed at the Research Laboratory of Functional Morphology and Genetics of the Research Center of National Pirogov Memorial Medical University, Vinnytsya within the limits of the general-university subject "Features of indicators of hemodynamics depending on parameters of a body structure at sportsmen of different kinds of sports" (State register number 0115U004045). The study involved 50 young men between the ages of 17 and 21 inclusive of athletics who had a high level of sportsmanship (from first adult to sports masters) with more than 3 years of athletic experience. All athletes had a track and field athletic load with maximum $(100 \mathrm{~m}, 200 \mathrm{~m}$ and $110 \mathrm{~m}$ hurdles) and sub-maximum (running on $400 \mathrm{~m}$ and $800 \mathrm{~m}$ ) work intensity.

We conducted a study of heart rate variability at the cardiac computer diagnostic complex "OPTW" on the recommendations of the European and North American Cardiac Association [25]. Indicators of variational heart rate pulsometry were determined, in particular: mode (MO), amplitude of mode (AMO), mean (NNM), minimum (MIN) and maximum (MAX) values of R-R intervals, variational range (VR); statistical cardiointervalographic indices: standard deviation of the length of normal R-R intervals (SDNN), square root of the sum of squares of difference of successive pairs of normal R-R intervals (RMSSD), percentage of the number of pairs of consecutive normal $\mathrm{R}-\mathrm{R}$ intervals differing by more than $50 \mathrm{~ms}$ interval pairs (PNN50); spectral performance, in particular: total write power in all ranges (FD), power at very low frequencies $\leq$ $0.04 \mathrm{~Hz}$ (waves of duration > $25 \mathrm{~s}$ ) (VLF), power at low frequencies of $0.04-0.15 \mathrm{~Hz}$ (waves of $6.5-25 \mathrm{~s}$ ) (LF), high frequency power $0.15-0.4 \mathrm{~Hz}$ (2.5-6.5 s wavelength) (HF), power ratio in the low and high frequency ranges (LF/HF).

We conducted an anthropometric study by the Bunak method [5], the determination of the component composition of the body mass by the Matejko method [14]. Score evaluation of the somatotype components was performed by a calculated modification of the Heath-Carter method [6]. After somatotypological analysis, it was found that the largest number of athletes (29 persons) belonged to the mesomorphic type of constitution. For this somatotype typology cohort in the "STATISTICA 5.5" package (license no. AXXR910A374605FA), we performed a correlation analysis using the nonparametric Spearman statistical method.

\section{Results}

After correlation analysis, it was found that most of the indices of variational heart rate pulsometry with anthropometric parameters of the body have not numerous, medium-strength reliable correlations. It was found that the mode had only one reliable correlation of the mean power with the thickness of the skin-fat fold on the side $(r=$ -0.36, $p=0.050)$. The amplitude of the mode was significantly correlated with the width of the distal epiphysis of the forearm $(r=0.37, p=0.050)$, the transverse infrasternal $(r=0.51, p=0.005)$ diameter, the anteriorposterior mid-sternal size $(r=0.37, p=0.050)$, and bone body weight $(r=0.37, p=0.050)$ and had unreliable correlations of mean force with the circumferential dimensions of the hip in the upper third $(r=-0.34, p=$ $0.057)$ and waist $(r=0.34, p=0.057)$, shoulder width $(r=$ $0.34, p=0.058)$, intertrochanteric distance $(r=0.34, p=$ $0.059)$. The average $R-R$ interval in mesomorphic athletes was found to be related to shoulder width $(r=0.38, p=$ $0.043)$, thickness of skin and fat folds on the abdomen ( $r=$ -0.34, $p=0.055)$ and sides $(r=-0.37, p=0.049)$. The maximum $R-R$ interval value in athletes was correlated with the height of the suprasternal anthropometric point ( $r$ $=0.34, p=0.056$ ), the thickness of the skin and fat folds under the shoulder blade $(r=-0.34, p=0.053)$ and on the side $(r=-0.40, p=0.033)$, the magnitude of the endomorphic $(r=-0.35, p=0.050)$ and mesomorphic $(r=$ $0.34, p=0.053$ ) components of the somatotype. And the minimum $R-R$ interval value was associated with the circumferential dimensions of the thigh in the upper third $(r$ $=-0.34, p=0.058)$ and chest on inhalation $(r=-0.38, p=$ $0.041)$ and exhalation $(r=-0.36, p=0.050)$, shoulder width $(r=0.35, p=0.050)$.

Variation span with indicators of external structure of the body had significant only inverse correlations, in particular with the width of the distal epiphysis of the forearm $(r=-0.36, p=0.050)$, transverse mid-sternal size $(r=-0.47$, $p=0.010)$, anterior-posterior mid-sternal size $(r=-0.48, p$ $=0.008)$ and acromial $(r=-0.37, p=0.047)$ thorax diameters, intercristal $(r=-0.34, p=0.057)$ and intertrochanteric $(r=$ - 
$0.37, p=0.049)$ pelvis distances.

The SDNN heart rate variability statistic was significantly correlated with transverse mid-sternal size $(r=-0.36, p=$ $0.049)$ and infrasternal $(r=-0.34, p=0.050)$ diameters and anterior-posterior mid-sternal size $(r=-0.40, p=0.034)$ and had direct unreliable correlations of mean strength with the circumferential hip dimensions $(r=0.31, p=0.069)$ and thigh in the lower third $(r=0.31, p=0.068)$. RMSSD was significantly correlated with the width of the distal epiphysis of the forearm $(r=-0.38, p=0.045)$ and the transverse infrasternal $(r=-0.34, p=0.051)$ and anteriorposterior mid-sternal size $(r=-0.44, p=0.016)$ diameters. PNN50 had inverse, mean correlation strength with width of distal shoulder epiphyses $(r=-0.40, p=0.031)$ and forearm $(r=-0.38, p=0.050)$; shoulder girdles $(r=-0.32, p$ $=0.079)$, chest at rest $(r=-0.36, p=0.050)$, deep exhalation $(r=-0.42, p=0.032)$ and inhalation $(r=-0.32, p=0.079)$; anterior-posterior mid-sternal size $(r=-0.43, p=0.020)$; intercristal distance $(r=-0.33, p=0.062)$ and intertrochanteric $(r=-0.38, p=0.044)$ distances of the pelvis and bone mass determined by the Matejko method $(r=-$ 0.36, $p=0.050$ ).

Most spectral indices of heart rate variability in athletes of mesomorphic somatotype had single reliable correlations with anthropometric and somatotypological parameters. The total recording power in all ranges had reliable direct correlations with only two girth body sizes: the hips $(r=0.38, p=0.041)$ and the thigh in the upper third $(r=0.36, p=0.050)$, and the unreliable mean power strength correlations were also detected with the thigh circumference in the lower third $(r=0.31, p=0.070)$, the thickness of the skin and fat folds under the shoulder blade $(r=-0.35, p=0.055)$ and the thigh $(r=-0.23, p=0.068))$, anterior-posterior mid-sternal size $(r=-0.35, p=0.056)$. The spectral index, which reflects the power at very low frequencies, was statistically significantly correlated with the transverse mid-sternal $(r=-0.45, p=0.016)$ diameter and the thickness of the skin-fat folds: under the shoulder blade $(r=-0.45, p=0.016)$, on the hip $(r=-0.43, p=0.020)$ and thigh $(r=-0.36, p=0.050)$. Inaccurate mean strength correlations, this indicator was also associated with fat components of the somatotype $(r=-0.34, p=0.059)$ and body weight $(r=-0.34, p=0.058)$ and thigh circumference $(r=0.34, p=0.058)$. It was found that the power in the low frequency range in mesomorphic athletes was the only reliable relationship with hip circumference $(r=0.37, p=$ 0.050 ), but unreliable correlations of mean strength were with length $(r=0.34, p=0.056)$ and area the surface of the body $(r=0.34, p=0.057)$, the thickness of the skin and fat folds on the hip $(r=-0.33, p=0.067)$ and the thigh $(r=-0.32$, $p=0.072)$, and muscle mass $(r=0.34, p=0.059)$. Power range of high frequencies had reliable direct correlations to the girth of the hip $(r=0.38, p=0.043)$ and the thigh $(r=$ $0.32, p=0.076$ ). The ratio of power in the low and high frequencies had enough numerical correlations of the average force with the indicators of the external structure of the body, in particular with the length $(r=0.32, p=0.079)$, mass $(r=0.34, p=0.058)$ and surface area $(r=0.35, p=$ $0.052)$ of the body, height of the suprasternal $(r=0.35, p=$ $0.054)$ and shoulder $(r=0.36, p=0.050)$ points, width of the hip epiphyses $(r=0.33, p=0.066)$, and thigh $(r=0.37$, $p=0.049)$, girth of neck $(r=0.32, p=0.081)$, waist $(r=0.49$, $p=0.006)$, hands $(r=0.43, p=0.014)$, chest on inspiration $(r=0.32, p=0.078)$, exhalation $(r=0.38, p=0.043)$, and pause $(r=0.39, p=0.040)$, thickness of skin-fat folds on chest $(r=-0.34, p=0.061)$, hips $(r=-0.32, p=0.073)$, thigh $(r=-0.37, p=0.048)$, bone mass $(r=0.39, p=0.021)$.

\section{Discussion}

A number of works have been devoted to the study of the relationship of individual indicators of the cardiovascular system with anthropo-somatotypological parameters in athletes [19, 21]. Relations between constitutional parameters and indexes of cardiointervalography have been studied in practically healthy individuals of all ages, sexes, different somatotypes, and with different types of hemodynamics [12, 25, 31].

Analyzing the peculiarities of the relationship between heart rate variability and external body structure in a group of highly skilled athletic athletes who belonged to the mesomorphic somatotype, it should be noted that there are significantly fewer statistically significant correlations than in previous studies. We found that the variations in heart rate pulsometry with somatic parameters did not have numerically significant and unreliable mean correlations. Mode, which indicates the dominant level of functioning of the sinus node [32], first of all, is determined by the characteristics of athletic activity, because it is practically unrelated to the anthropometric parameters of the body. The amplitude of mode is an indicator that reflects the degree of mobilizing influence of the sympathetic division of the autonomic nervous system [16, 32, 35], which is directly proportional to the transverse and circumferential dimensions of the trunk. Therefore, it can be assumed that athletes with increased width and thickness of the trunk will have a more pronounced sympathicotonia. Indicators of variational heart rate pulsometry, which are based on R$R$ interval values (NNM, MAX), have been associated with subcutaneous fat deposition. Moreover, inverse correlations were established between the thickness of the skin-fat folds, the magnitude of the endomorphic and mesomorphic components of the somatotype. The revealed feature indicates that the decrease of fat component in athletes of mesomorphic somatotype will increase the influence on the heart of the parasympathetic department. The decrease in the minimum value of $R-R$ intervals is accompanied by a greater influence of the sympathetic division of the autonomic nervous system [33, 35], so the results obtained by us regarding the correlations of this variational index indicate that, with a decrease in the circumference of the thigh and chest and an increase in the width of the shoulders, the cardiovascular system will 
be more strongly influenced by the sympathetic department.

According to the results of correlation analysis of the statistical index of heart rate variability SDNN, which is a standard deviation of R-R intervals between heart rate of normal sinus rhythm [16, 33], it can be predicted that as the chest diameters decrease and the hip and thigh circumferences increase, the athletes will be affected on the work of the sinus node of the heart of the autonomic nervous system and various humoral factors. The decrease in thickness and width of the chest and width of the distal epiphysis of the forearm will be accompanied by an increase in the standard deviation of the difference of consecutive R-R intervals, and hence the predominant parasympathetic activity, which may reflect sinus arrhythmia associated with breathing [33]. PNN50 has the highest strength and highest correlation with anthropometric dimensions among all statistical indicators of heart rate variability. It is interrelated with 10 constitutional parameters. All significant correlations are reversed, indicating that with decreasing diameters of the upper extremity, chest and pelvis, girth of the shoulder and chest and bone mass, the total number of consecutive pairs of R-R intervals differing by more than $50 \mathrm{~ms}$ from the total the number of consecutive pairs of intervals. And in athletes of the mesomorphic somatotype, with such a combination, respiratory arrhythmia will have a more pronounced effect on heart rate variability.

Thus, statistical indicators of heart rate variability with constitutional parameters have mainly inverse correlations. It should be noted that the anterior-posterior mid-sternal size, which indicates the thickness of the chest, is interrelated with all cardiointervalographic indicators of this group and the strength of correlations is highest $(r=-0.40--0.44)$.

It is established that spectral indices have the lowest number, in comparison with other groups of cardiointervalographic parameters, reliable correlations with the constitutional characteristics of the organism, but thus unreliable average correlations were revealed. The power at very low frequencies, which is closely related to the psycho-emotional stress, the activity of the neurohumoral regulation of the angiotensive, thermoregulatory, chemoreceptive systems [4, 17, 32], increases with the reduction of the mid-sternal diameter and the thickness of the skin and fat. With increasing body

\section{References}

[1] Adhikari, A., Nahida, P., Islam, R. N., \& Kitab, A. (2014). Importance of Anthropometric Characteristics in Athletic Performance from the Perspective of Bangladeshi National Level Athletes Performance and Body Type. American Journal of Sports Science and Medicine, 2(4), 123-127. doi: 10.12691/ ajssm-2-4-1D

[2] Bacciotti, S., Baxter-Jones, A., Gaya, A., \& Maia, J. (2018). Body physique and proportionality of Brazilian female artistic gymnasts. J. Sports Sci., 36(7), 749-756. doi: 10.1080/ 02640414.2017.1340655

[3] Barth, M., Emrich, E., \& Daumann, F. (2018). Approaches and length and better development of the muscles of the lower extremity, we observed mesomorph athletes increase in power in the low frequency range and therefore sympathetic-parasympathetic modulation of the baroreflex nature [4]. Power in the high frequency range, which reflects the activity of the parasympathetic part of the autonomic nervous system $[4,17]$, had the least significant correlations (only with hip and thigh circumference). In athletes, these dimensions are associated with athletic performance. And according to the results of the correlation analysis conducted by us, their increase will lead to a more pronounced parasympathetic influence on the heart rate variability.

\section{Conclusions}

1. Cardiointervalographic indexes were found to be statistically significantly correlated with small in number body sizes and somatotype components and body weights in adolescent athletes belonging to the mesomorphic somatotype.

2. Variational heart pulsometry rate indicators have not numerically significant and unreliable relationships of mean strength (closer to weak $r=0.33-0.39$ ) to somatic parameters, except for the transverse and anterior-posterior thorax diameters $(r=0.48-0.51)$. The data of correlation analysis of indices of variational pulsometry showed that in athletes with increase in width and thickness of the torso and decrease in the circumference of the shin and chest was more pronounced sympathicotonia, and with the reduction of fat component increased the influence on the heart of the parasympathetic system.

3. It was found that statistical indicators of heart rate variability with constitutional parameters had significant inverse correlations of mean power. The anterior-posterior mid-sternal size had the highest correlation strength $(r=-0.40--0.44)$ with all cardiointervalographic indices of this group. Among all statistical indicators of heart rate variability, the PNN50 had the strongest and most significant correlations with anthropometric dimensions.

4. The least significant correlations with constitutional characteristics in mesomorphic athletes had spectral indices related to the thickness of the skin-fat folds, trunk diameters and circumferences of the lower extremity segments.

methods used for measuring organizational performance in national sport governing bodies from 1986 to 2014. A systematized review. Current Issues in Sport Science, (3), 1-22. doi: 10.15203/CISS 2018.010

[4] Bricout, V., Dechenaud, S., \& Favre-Juvin, A. (2010). Analyses of heart rate variability in young soccer players: The effects of sport activity. Autonomic neuroscience: basic \& clinical, 154(1-2), 112-116. doi: 10.1016/j.autneu.2009.12.001

[5] Bunak, V. V. (1941). Anthropometry: a practical course. M.: Uchpedgiz.

[6] Carter, J. L., \& Heath, B. H. (1990). Somatotyping - development 
and applications. Cambridge University Press.

[7] Di Rienzo, F., Hoyek, N., Collet, C., \& Guillot, A. (2014). Physiological changes in response to apnea impact the timing of motor representations: a preliminary study. Behavioral and Brain Functions, 10(1), 15. doi: 10.1186/1744-9081-10-15

[8] D'Silva, A., \& Sharma, S. (2014). Exercise, the athlete's heart, and sudden cardiac death. Phys. Sportsmed, 42(2), 100-113.

[9] Flatt, A. A., Esco, M. R., Allen, J. R., \& Robinson, J. B. (2018). Heart Rate Variability and Training Load Among National Collegiate Athletic Association Division 1 College Football Players Throughout Spring Camp. J. Strength Cond. Res., 32(11), 3127-3134. doi: 10.1519/JSC.0000000000002241

[10] Ishchenko, G. O. (2014). Features of correlation of cardiointervalography indices and anthropo-somatotypological parameters of practically healthy men and women of Podillya of the first mature age. Ukrainian Medical Almanac, 6(6), 2023.

[11] Kellmann, M., Bertollo, M., Bosquet, L., \& Brink, M. (2018). Recovery and Performance in Sport: Consensus Statement. International J. of sports physiology and performance, 13(2), 240-245. doi: 10.1123/ijspp.2017-0759

[12] Koveshnikov, V. G., \& Nikityuk, B. A. (1992). Medical anthropology. Kiev: Health.

[13] Malikhina, T., \& Serdyuk, N. (2015). Psychology of sport. Berdyansk: Berdyansk State Pedagogical University.

[14] Malik, M., Bigger, J. T., Camm, A. J., Kleiger, R. E., Malliani, A., Moss, A. J., \& Schwartz, P. J. (1996). Heart rate variability. Standards of measurement, physiological interpretation, and clinical use. Task Force of the European Society of Cardiology and the North American Society of Pacing and Electrophysiology. European Heart Journal, (17), 354-381.

[15] Mazon, J. H., Gastaldi, A. C., Martins-Pinge, M. C., Eduardo de Araújo J. \& Dutra de Souza, H. C. (2015). Study of Heart Rate Variability and Stress Markers in Basketball Players Submitted to Selective Loads Periodization System. American Journal of Sports Science, 3(3), 46-51. doi: 10.11648/ j.ajss.20150303.12

[16] Moroz, V. M., Khapitska, O. P., \& Sarafinyuk, L. A. (2016). The interrelation of rheovasographic parameters of the hip with external indicators of body structure in athletes of different sports. Reports of Morphology, 22(2), 372-379.

[17] Moroz, V. M., Sarafinyuk, L. A., \& Khapitska, O. P. (2016). Correlation of hemodynamic parameters hip with constitutional characteristics of sportsmen with mesomorphicsomato type. Biomedical and biosocial anthropology, 27, 112-118.

[18] Myer, G. D., Jayanthi, N., Difiori, J. P., Faigenbaum, A. D., Kiefer, A. W., Logerstedt, D., \& Micheli, L. J. (2015). Does Early Sports Specialization Increase Negative Outcomes and Reduce the Opportunity for Success in Young Athletes? Sports Health, 7(5), 437-442. doi: 10.1177/1941738115598747

[19] Paul, M., \& Garg, K. (2012). The effect of heart rate variability biofeedback on performance psychology of basketball players. Appl. Psychophysiol. Biofeedback, 37(2), 131-44. doi: 10.1007/s10484-012-9185-2

[20] Pereira, L. A., Cal Abad, C. C., Leiva, D. F., \& Oliveira, G.
(2019). Relationship Between Resting Heart Rate Variability and Intermittent Endurance Performance in Novice Soccer Players. J. Research Quarterly for Exercise and Sport, (90), 355-361. doi: 10.1080/02701367.2019.1601666

[21] Piliponova, V. V. (2011). Relationships between cardiointervalography indices and anthropo-somatotypological parameters in healthy urban youth of Podillya of different somatotypes. Advances in Clinical and Experimental Medicine, 2(13), 98-100.

[22] Morales, A. P., Sampaio-Jorge, F., Rangel, L. F. C., Coe1ho, G. M. O., Leite, T. C., \& Ribeiro, B. G. (2014). Heart rate variability responses in vertical jump performance of basketball players. Int. J. Sports Sci., 4(2), 72-78. doi: 10.5923/ j.sports.20140402.06

[23] Priymak, S. G., \& Terentieva, N. O. (2017). Somatologic characteristics of biathlon students' body constitution in predicting of their successfulness. Pedagogics, psychology, medical-biological problems of physical training and sports, 21(4), 192-199. doi: 10.15561/18189172.2017.0408

[24] Ramos-Campo, D. J., Rubio-Arias, J. A., Ávila-Gandía, V., \& Marín-Pagán, C. (2017). Heart rate variability to assess ventilatory thresholds in professional basketball players. $J$. Sport Health Sci., 6(4), 468-473. doi: 10.1016/ j.jshs.2016.01.002

[25] Rave, G., Fortrat, J-O., Dawson, B., \& Carre, F. (2018). Heart rate recovery and heart rate variability: use and relevance in European professional soccer. International Journal of Performance Analysis in Sport, (18), 168-183. doi: 10.1080/ 24748668.2018.1460053

[26] Rollo, S., Tracey, J., \& Prapavessis, H. (2017). Effects of a Heart Rate Variability Biofeedback Intervention on Athletes Psychological Responses Following Injury: A Pilot Study. Int. J. Sports Exerc. Med., 3(081), 1-14. doi: 10.23937/2469-5718/ 1510081

[27] Sergeta, I. V., Gunas, I. V., Kovalchuk, V. V., \& Shipitsina, O. V. (2017). Features of correlation of heart rate variability with anthropo-somatotypologic body parameters of healthy healthy girls with different types of hemodynamics. J. of Morphology, 23(2), 327-331.

[28] Shakhanova, A. V., Kuzmin, A. A., \&Agirov, A. Kh. (2012). The functional and adaptive capabilities of young 10-15 year-old football and basketball players, depending on the somatotype. $J$. of the Adygea State University, (3), 5-13.

[29] Shlak, N. E. (2015). Express estimation of functional readiness of an organism of the athlete for training and competitive actions (according to the analysis of heart rate variability). Science and sports: current trends, 4(9), 5-15.

[30] Stanković, D., Pavlović, R., Petković, E., Raković, A. \& Puletić, M. (2018). The somatotypes and body composition of elite track and field athletes and swimmers. International Journal of Sports Science, 8(3), 67-77. doi: 10.5923/ j.sports.20180803.01.

[31] Yakovleva, L. V., \& Guzel, N. S. (2015). Heart rate variability and psychological status in young hockey players. Kazan Medical Journal, 96(4), 675-679.

\section{КОРЕЛЯЦІЇ КАРДІОІНТЕРВАЛОГРАФІЧНИХ ПОКАЗНИКІВ 3 КОНСТИТУЦІОНАЛЬНИМИ ХАРАКТЕРИСТИКАМИ У ЛЕГКОАТЛЕТІВ МЕЗОМОРФНОГО СОМАТОТИПУ}

\section{Сарафинюк Л.А., Сивак А.В., Якушева Ю.І., Борейко Т.І.}

Тема спорту, фрізичної тренованості і адаптаційних можливостей людини до впливу фрізичних навантажень різної інтенсивності за останні роки набула високої актуальності. Мета роботи - встановити кореляції між показниками варіабельності серцевого ритму та параметрами зовнішньої будови тіла у легкоатлетів юнацького віку мезоморфного соматотипу. У дослідженні взяли участь 29 легкоатлетів у віці від 17 до 21 року з високим рівнем спортивної майстерності і стажем більще 3 років. Всі спортсмени мали легкоатлетичне навантаження бігового спрямування з максимальною (біг на 
100 м, 200 м та 110 м з бар'єрами) і субмаксимальною (біг на 400 м і 800 м ) інтенсивністю роботи. Нами було проведене дослідження варіабельності серцевого ритму на кардіологічному комп'ютерному діагностичному комплексі "ОРТW" за рекомендаціями Європейської та Північно-американської кардіологічної асоціації (1996). Визначали показники варіаційної пульсометрії, статистичні та спектральні кардіоінтервалографрічні показники. Антропометрію проводили за методом Бунака (1941), соматотипологічне дослідження - за розрахунковою модифрікацією метода Heath-Carter (1990), визначення компонентного складу маси тіла за методом Матейко (1921). У пакеті "STATISTICA 5.5" був проведений кореляційний аналіз із використанням непараметричного статистичного методу Спірмена. Встановлено, що кардіоінтервалографрічні показники статистично значуще корелювали з невеликою кількістю розмірів тіла і компонентами соматотипу та маси тіла у легкоатлетів юнацького віку, які належали до мезоморфного соматотипу. Показники варіаційної пульсометрії мали не чисельні достовірні та недостовірні зв'язки середньої сили з соматичними параметрами. Дані кореляційного аналізу показників варіаційної пульсометрії свідчили, що у легкоатлетів із збільшенням ширини та товщини тулуба і зменшенням обхвату гомілки та грудної клітки була більш виражена симпатикотонія, а при зменшенні жирового компонента збільшувався вплив на роботу серия парасимпатичного відділу автономної нервової системи. Статистичні показники варіабельності серцевого ритму з конституціональними параметрами мали значущі зворотні кореляції середньої сили. Серед усіх статистичних показників варіабельності серцевого ритму PNN50 мав найсильніші та найчисельніші кореляції з антропометричними розмірами. Найменшу кількість достовірних кореляцій з конституціональними характеристиками у легкоатлетів-мезоморфів мали спектральні показники, які пов'язані з товщиною шкірно-жирових складок, діаметрами тулуба та обхватами сегментів нижньої кінцівки.

Ключові слова: кореляції, кардіоінтервалографрічні показники, антропометричні розміри, соматотип, легкоатлети.

КОРРЕЛЯЦИИ КАРДИОИНТЕРВАЛОГРАФИЧЕСКИХ ПОКАЗАТЕЛЕЙ С КОНСТИТУЦИОНАЛЬНЫМИ ХАРАКТЕРИСТИКАМИ У ЛЕГКОАТЛЕТОВ МЕЗОМОРФНОГО СОМАТОТИПА

Сарафинюк Л.А., Сивак А.В., Якушева Ю.И., Борейко Т.И.

Тема спорта, физической тренированности и адаптационных возможностей человека к воздействию фризических нагрузок различной интенсивности за последние годы приобрела высокую актуальность. Цель работы - установить корреляции между показателями вариабельности сердечного ритма и параметрами внешнего строения тела у легкоатлетов юношеского возраста мезоморфного соматотипа. В исследовании приняли участие 29 легкоатлетов в возрасте от 17 до 21 года с высоким уровнем спортивного мастерства и стажем более 3 лет. Все спортсмены имели легкоатлетическая нагрузку бегового направления с максимальной (бег на 100 м, 200 м и 110 м с барьерами) и субмаксимальной (бег на 400 м и 800 м) интенсивностью работы. Нами было проведено исследование вариабельности сердечного ритма на кардиологическом компьютерном диагностическом комплексе "ОРТW" по рекомендациям Европейской и Североамериканской кардиологической ассоциации (1996). Определяли показатели вариационной пульсометрии, статистические и спектральные кардиоинтервалографические показатели. Антропометрию проводили по методу Бунака (1941), соматотипологические исследования - по расчетной модификации метода Hеath-Carter (1990), определение компонентного состава массы тела по методу Матейко (1921). В пакете "STATISTICA 5.5" был проведен корреляционный анализ с использованием непараметрического статистического метода Спирмена. Установлено, что кардиоинтервалографрические показатели статистически значимо коррелировали с небольшим количеством размеров тела и компонентами соматотипа и массы тела у легкоатлетов юношеского возраста, принадлежащих к мезоморфному соматотипу. Показатели вариационной пульсометрии имели немногочисленные достоверные и недостоверные связи средней силы с соматическими параметрами. Данные корреляционного анализа показателей вариационной пульсометрии свидетельствовали, что у легкоатлетов с увеличением ширины и толщины туловища и уменьшением охвата голени и грудной клетки была более выражена симпатикотония, а при уменьшении жирового компонента увеличивалось влияние на работу сердиа парасимпатического отдела автономной нервной системы. Статистические показатели вариабельности сердечного ритма с конституциональными параметрами имели значимые обратные корреляции средней силы. Среди всех статистических показателей вариабельности сердечного ритма PNN50 имел сильные и самые многочисленные корреляции с антропометрическими размерами. Наименьшее количество достоверных корреляций с конституциональными характеристиками у легкоатлетов-мезоморфов имели спектральные показатели, связанные с толщиной кожно-жировых складок, диаметрами туловища и обхватами сегментов нижней конечности.

Ключевые слова: корреляции, кардиоинтервалографические показатели, антропометрические размеры, соматотип, легкоатлеты. 